http://journal.lldikti9.id/plenojure

Vol. 9, No. 1, April 2020, pp. 16-35

p-ISSN: 2301-7686 dan e-ISSN: 2684-8449

DOI: https://doi.org/10.37541/plenojure.v9i1.328

\title{
Pelaksanaan Pembagian Harta Bersama dalam Perkawinan Poligami Setelah Perceraian
}

\author{
Muhammad Kamran Imran \\ Ilmu Hukum, Program Pascasarjana Universitas Muslim Indonesia \\ Email Correspondensi: muhammadkamran030196@gmail.com \\ No. HP Correspondensi: +62 813-4108-1115
}

\section{PLENVG}

Jurnal Ilmu Hukum

LL-DIKTI Wilayah IX

Sulawesi

\author{
Artikel history: \\ Received : 07 Maret 2020 \\ Revised : 22 Maret 2020 \\ Accepted : $\quad 23$ Maret 2020
}

Abstrak. Penelitian ini dilakukan dengan bertujuan: Untuk mengetahui dan memahami efektivitas pelaksanaan pembagian harta bersama dalam perkawinan Poligami jika terjadi perceraian. Jenis penelitian ini adalah penelitian hukum dengan tipe penelitian hukum empiris atau (socio legal study research). Hasil Penelitian ini menunjukkan bahwa: Efektivitas pelaksanaan pembagian harta bersama dalam perkawinan poligami jika terjadi perceraian adalah kurang efektif. Oleh karena dipengaruhi oleh beberapa faktor dan tidak tercapainya sasaran atau tujuan yang ditentukan sebelumnya, sehingga derajat ukuran efektivitas tidak terpenuhi. Rekomendasi: (1) Perlu Pengaturan Hukum Positif yang mengatur syarat mutlak berpoligami, harta bersama dengan istri terdahulu wajib dipisahkan dengan permohonan izin poligami bersamaan dengan penetapan harta bersama, untuk menghindari terjadinya penyelundupan hak istri terdahulu oleh suami dan memberikan kepastian hukum hak-hak istri terdahulu mengenai harta bersamanya. (2) Bahwa faktorfaktor yang bisa mempengaruhi efektivitas pelaksanaan pembagian harta bersama dalam perkawinan poligami, penegak hukum harus mengupayakan untuk mencegah hal tersebut, sehingga tolak ukur efektivitas pelaksanaan pembagian harta bersama dalam perkawinan poligami setelah perceraian dapat berjalan efektif.

Abstract. The This research was conducted to find out and understand the effectiveness of the implementation of the sharing of joint property in a polygamy marriage in case of divorce. This type of research is legal research with empirical legal research type (Socio Legal Study Research). The results of this study indicate that: The effectiveness of the distribution of shared assets in polygamy marriages in the event of a divorce is less effective. Because it is influenced by several factors and not achieving the goals or objectives determined beforehand, so the degree of measure of effectiveness is not met. Recommendations: (1) A Positive Legal Arrangement is required that regulates the absolute requirements of polygamy, shared assets with the previous wife must be separated from the request for a polygamy permit together with the determination of shared assets, 
Pleno Jure, Vol. 9 (1), Muhammad Kamran Imran, Pelaksanaan Pembagian Harta ...

to avoid smuggling the rights of the previous wife by the husband and provide legal certainty of the rights of the previous wife regarding property with him. (2) That the factors that can affect the effectiveness of the distribution of shared assets in polygamy marriages, law enforcement must strive to prevent this, so that the effectiveness of the distribution of shared assets in polygamy marriages after divorce can be effective.

Keywords:

Perkawinan; Poligami.

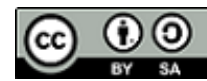

artikel dengan akses terbuka dibawah lisensi CC BY-SA 4.0

\section{PENDAHULUAN}

Poligami merupakan suatu realitas hukum dalam masyarakat yang akhir-akhir ini menjadi suatu perbincangan hangat serta menimbulkan pro dan kontra. Poligami sendiri mempunyai arti suatu sistem perkawinan antara satu orang pria dengan lebih dari seorang istri. di mana poligami ditegaskan dalam Al-Qur'an Surah An-Nisaa ayat (3) bahwa:

"Dan jika kamu takut tidak akan dapat berlaku adil terhadap (hakhak) perempuan yang yatim (bilamana kamu mengawininya), maka kawinilah wanita-wanita (lain) yang kamu senangi: dua, tiga atau empat. Kemudian jika kamu takut tidak akan dapat berlaku adil, maka (kawinilah) seorang saja, atau budak-budak yang kamu miliki. Yang demikian itu adalah lebih dekat kepada tidak berbuat aniaya".

Perkawinan adalah salah satu peristiwa yang sangat penting dalam kehidupan masyarakat Indonesia. Akibat perkawinan itu tidak hanya menyangkut hubungan hukum antara calon suami isteri, tetapi juga dengan orang tua kedua belah pihak, saudara-saudara, bahkan keluarga-keluarga kedua belah pihak. Pada saat terjadinya perkawinan, pasangan suami isteri telah terikat sebuah keluarga sehingga sering terjadi antara suami isteri mencari penghasilan bersama sehingga timbullah harta kekayaan dalam keluarga. Harta kekayaan dalam perkawinan bisa berupa harta yang dihasilkan isteri maupun yang dihasilkan suami pada saat perkawinan.

Berdasarkan Pasal 35 ayat (1) Undang-Undang Republik Indonesia Nomor 16 Tahun 2019 tentang Perubahan Atas Undang-Undang Nomor 1 Tahun 1974 tentang Perkawinan (selanjutnya disebut UU No. 16 Tahun 2019) mengatur bahwa "Harta benda yang diperoleh selama perkawinan menjadi harta bersama" jo. Pasal 1 huruf f Instruksi Presiden Republik Indonesia Nomor 1 Tahun 1991 tentang Penyebarluasan Kompilasi Hukum Islam(selanjutnya disebut Inpres No. 1 Tahun 1991) mengartikan bahwa:

"Harta kekayaan dalam perkawinan atau Syirkah adalah harta yang diperoleh baik sendiri-sendiri atau bersama suami-isteri selama dalam ikatan perkawinan berlangsung selanjutnya disebut harta bersama, tanpa mempersoalkan terdaftar atas nama siapapun." 
Dari ketentuan di atas dapat diperoleh sebuah penjelasan bahwa terbentuknya harta bersama dalam perkawinan adalah sejak saat tanggal terjadinya pernikahan sampai tanggal ikatan perkawinan itu berakhir, artinya pada saat terjadi pernikahan antara suami isteri terjadi kesatuan harta pada harta kekayaan apakah harta itu diperoleh baik sendiri-sendiri atau bersama suami isteri selama dalam ikatan perkawinan berlangsung.

Pada dasarnya Islam menghendaki setiap perkawinan itu berlangsung selama-lamanya, Tetapi walaupun Islam menghendaki suatu kelanggengan hidup berumah tangga tidak menutup kemungkinan nyata bahwa hidup dan kehidupan manusia itu tidak langgeng dan ada kalanya menemui suatu kegagalan. Akibat kegagalan dalam rumah tangga akan menimbulkan masalah hukum adalah putusnya perkawinan.

Selanjutnya, berdasarkan Pasal 38 UU No. 16 Tahun 2019 mengatur bahwa perkawinan dapat putus karena:
a. kematian;
b. perceraian; dan
c. atas keputusan pengadilan.

Putusnya perkawinan karena perceraian dan ini akan menimbulkan akibat hukum yang akan mempengaruhi hak dan kewajiban antara mantan suami dan mantan isteri serta anak yang lahir dari perkawinan yang sah tersebut. Demikian juga mengenai harta bersama yang diperoleh sepanjang perkawinan maupun harta bawaan dari masing-masing suami isteri. Menurut fenomena hukum bahwa dalam perkawinan poligami, yaitu suatu sistem perkawinan antara satu orang pria dengan lebih dari seorang isteri. Dalam perkawinan poligami ini tidak menutup kemungkinan terjadi penyeludupan hak isteri terdahulu oleh suami. Biasa terjadi ketika si isteri telah memberi izin kepada suaminya untuk menikah lagi, pada akhirnya isteri terdahulu sering tidak diperhatikan, sehingga hak-hak dari harta bersama tereduksi oleh kepentingan isteri kedua.

Berdasarkan uraian tersebut di atas, maka tujuan penelitian ini adalah untuk mengetahui dan memahami efektivitas pelaksanaan pembagian harta bersama jika terjadi perceraian, dengan rumusan masalah penelitian ini, untuk penyusunan penulisan hukum mengenai bagaimanakah efektivitas pelaksanaan pembagian harta bersama dalam perkawinan poligami jika terjadi perceraian.

\section{METODE}

Jenis penelitian ini adalah penelitian hukum dengan tipe penelitian hukum empiris atau (socio legal study research). Lokasi penelitian ini adalah dilakukan di Kota Makassar yaitu Pengadilan Agama Klas 1A Makassar, di Kantor Advokat, Kantor Notaris dan Ulama yang dipandang mengetahui permasalahan yang dibahas dalam penelitian ini. Sedangkan populasi penelitian ini adalah segenap objek pengamatan penelitian dari populasi tersebutditarik sampel yang memiliki segenap populasi berdasarkan karakternya, yang terdiri Hakim Pengadilan Agama Klas 1A Makassar sebanyak 15 (lima belas); Panitera Pengadilan Agama Klas 1A Makassar sebanyak 10 (sepuluh); Juru Sita Pengadilan Agama Klas 1A 
Makassar sebanyak 5 (lima); Advokat sebanyak 30 (tiga puluh); Notaris sebanyak 5 (lima); Ulama sebanyak 5 (lima) dan Masyarakat berperkara sebanyak 10 (sepuluh). Jenis dan sumber data yaitu data primer adalah data yang peroleh langsung di lokasi penelitian, data yang diperoleh melalui data primer yaitu di tempat penelitian melalui hasil wawancara secara langsung kepada para responden/informan yang berkompeten dengan masalah yang sedang dibahas, dalam hal ini adalah Hakim Pengadilan Agama Kelas 1A Makassar, Advokat, dan Ulama yang dipandang banyak mengetahui permasalahan yang dibahas dalam penelitian ini. Sedangkan data sekunder adalah data yang diperoleh penulis dari hasil kajian pustaka melalui penelusuran bahan-bahan pustaka seperti literature Buku, Jurnal ilmiah, Artikel Ilmiah, Tesis, Peraturan Perundang-undangan serta dokumen-dokumen resmi serta tulisan-tulisan lain yang mempunyai relevan dengan pembahasan penelitian ini agar dapat memberikan gambaran dan dasar pengetahuan melalui kerangka berpikir yang tajam, logis dan sistematika. Teknik pengumpulan data yaitu dengan dokumentasi; wawancara; kuesioner. Sedangkan Dalam menganalisis data digunakan analisis Kualitatif adalah upaya yang dilakukan dengan mengolah data empiris maupun analisis kuantitatif adalah suatu teknik yang menggambarkan dan menginterpretasikan datadata yang telah terkumpul, sehingga diperoleh gambaran secara umum dan menyeluruh tentang keadaan sebenarnya. Sedangkan hasil kuesioner dianalisis secara kualitatif dalam bentuk tabulasi Frekuensi dan distribusi persentasi.

\section{HASIL DAN PEMBAHASAN}

\section{A. Pembagian Harta Benda Perkawinan Poligami Berdasarkan UU No. 16 Tahun 2019}

Sayuti Thalib mendefinisikan perkawinan/nikah sebagai perjanjian suci membentuk keluarga antara seorang laki-laki dengan seorang perempuan. ${ }^{1}$ Perkawinan adalah salah satu peristiwa yang sangat penting dalam kehidupan masyarakat Indonesia. Akibat perkawinan itu tidak hanya menyangkut hubungan hukum antara calon suami isteri, tetapi juga dengan orang tua kedua belah pihak, saudarasaudara, bahkan keluarga-keluarga kedua belah pihak.

Poligami merupakan suatu realitas hukum dalam masyarakat yang akhir-akhir ini menjadi suatu perbincangan hangat serta menimbulkan pro dan kontra. Poligami sendiri mempunyai arti suatu sistem perkawinan antara satu orang pria dengan lebih dari seorang isteri. Pembagian harta gono gini termasuk masalah yang cukup rumit dipecahkan dalam sebuah perkawinan yang berujung pada perceraian, Masalah ini bersifat sangat sensitif karena berkenaan dengan soal harta benda yang dimiliki oleh suami dan istri, baik yang menjadi hak milik bersama (harta gono gini) atau hak milik perseorangan (harta bawaan). Berdasarkan Pasal 35 ayat (1) UU No. 16 Tahun 2019 mengatur bahwa "Harta benda yang diperoleh selama perkawinan menjadi harta bersama" jo. Pasal 36 ayat (1) UU No. 16 Tahun 2019 mengatur bahwa "Mengenai

${ }^{1}$ Yunus, A. (2020). Hukum Perkawinan dan Itsbat Nikah: Antara Perlindungan dan Kepastian Hukum. Makassar: Humanities Genius, hlm, 27. 
harta bersama, suami atau isteri dapat bertindak atas persetujuan kedua belah pihak" jo. Pasal 37 UU No. 16 Tahun 2019 mengatur bahwa "Bila perkawinan putus karena perceraian, harta bersama diatur menurut hukumnya masing-masing". Adapun berdasarkan Pasal 38 UU No. 16 Tahun 2019 mengatur bahwa perkawinan dapat putus karena:
a. kematian;
b. perceraian; dan
c. atas keputusan pengadilan.

Dari ketentuan di atas dapat diperoleh sebuah penjelasan bahwa terbentuknya harta bersama dalam perkawinan adalah sejak saat tanggal terjadinya pernikahan sampai tanggal ikatan perkawinan itu berakhir, artinya pada saat terjadi pernikahan antara suami isteri terjadi kesatuan harta pada harta kekayaan apakah harta itu diperoleh baik sendiri-sendiri atau bersama suami isteri selama dalam ikatan perkawinan berlangsung

Persoalan harta bersama dalam perkawinan poligami akan menjadi persoalan yang cukup pelik dan rumit, dan dapat berakibatkan pada kerugian bagi istri terdahulu akibat terjadinya penyeludupan hak isteri terdahulu oleh suami apabila tidak dilakukan pembukuan yang rapi dan akuntabel mengenai pemisahan harta bersama. Biasa terjadi, ketika si istri telah memberi izin kepada suaminya untuk menikah lagi, pada akhirnya istri terdahulu sering tidak diperhatikan, dan hakhaknya dari harta bersama tereduksi oleh kepentingan isteri kedua. Kalau memperhatikan asal usul harta yang di dapat suami istri dapat disimpulkan dalam tiga sumber: ${ }^{2}$

1. Harta masing-masing suami isteri yang telah dimilikinya sebelum kawin baik diperolehnya karena mendapat warisan atau usahausaha lainnya, disebut sebagai harta bawaan.

2. Harta masing-masing suami istri yang diperolehnya selama berada dalam hubungan perkawinan, tetapi diperoleh bukan karena usaha mereka bersama-sama maupun sendiri-sendiri, tetapi diperolehnya karena hibah, warisan, ataupun wasiat untuk masing-masing disebut harta bawaan.

3. Harta yang diperoleh setelah mereka berada dalam hubungan perkawinan atas usaha mereka berdua atau salah satu pihak dari mereka disebut harta pencaharian.

Harta yang bersumber dari hibah, wasiat, hadiah, sodaqah atau harta warisan, baik yang diterima sebelum perkawinan maupun selama perkawinan statusnya adalah tetap menjadi milik masing-masing suami atau isteri. Harta yang bersumber dari hasil usaha sendiri sebelum perkawinan tetap dikuasai oleh masing-masing suami atau istri. Selanjutnya harta yang diperoleh pada saat terjadinya perkawinan, ada yang menjadi milik istri dan ada yang menjadi milik suami, ada yang menjadi milik orang 
tua pasangan suami istri, dan ada pula yang dibagi-bagikan kepada sanak saudara pasangan suami isteri. Sedangkan harta yang dihasilkan oleh suami istri selama dalam perkawinan dikuasai bersama oleh suami isteri. Berdasarkan Pasal 35 UU No. 16 Tahun 2019 mengatur bahwa:

(1) Harta benda yang diperoleh selama perkawinan menjadi harta bersama.

(2) Harta bawaan dari masing-masing suami dan isteri dan harta benda yang diperoleh masing-masing sebagai hadiah atau warisan, adalah dibawah penguasaan masing-masing sepanjang para pihak tidak menentukan lain.

Selanjutnya, berdasarkan Pasal 36 UU No. 16 Tahun 2019 mengatur bahwa:

(1) Mengenai harta bersama, suami atau isteri dapat bertindak atas persetujuan kedua belah pihak.

(2) Mengenai harta bawaan masing-masing, suami dan isteri mempunyai hak sepenuhnya untuk melakukan perbuatan hukum mengenai harta bendanya.

Lebih lanjut, berdasarkan Pasal 37 UU No. 16 Tahun 2019 mengatur bahwa "Bila perkawinan putus karena perceraian, harta bersama diatur menurut hukumnya masing-masing". Suami yang menerima pemberian baik hibah, warisan dan sebagainya berhak menguasai sepenuhnya harta yang diterimanya itu tanpa harus masuk ke dalam harta percampuran perkawinan. Demikian juga sebaliknya bagi isteri yang menerima hibah, warisan atau lainnya berhak menguasai sepenuhnya, hal ini juga berlaku bagi harta bawaan yang ada sebelum perkawinan kedua belah pihak juga berhak memiliki sendiri-sendiri tanpa campur tangan pihak lain. ${ }^{3}$

Harta bersama antara suami isteri baru dapat dibagi apabila hubungan perkawinan itu sudah terputus, hubungan perkawinan itu dapat terputus dengan alasan adanya kematian, perceraian dan dapat juga oleh keputusan pengadilan. Pelaksanaan pembagian harta bersama dalam perkawinan poligami setelah perceraian, ditegaskan pada Pasal 65 UU No. 16 Tahun 2019 mengatur bahwa:

(1) Dalam hal seorang suami beristeri lebih dari seorang baik berdasarkan hukum lama maupun berdasarkan Pasal 3 ayat (2) Undang-Undang ini maka berlakulah ketentuan-ketentuan berikut:

a. suami wajib memberikan jaminan hidup yang sama kepada semua isteri dan anaknya;

b. isteri yang kedua dan seterusnya tidak mempunyai hak atas harta bersama yang telah ada sebelum perkawinan dengan isteri kedua atau berikutnya itu terjadi;

c. semua isteri mempunyai hak yang sama atas harta bersama yang terjadi sejak perkawinannya masing-masing.

${ }^{3}$ Susanto, H. (2008). Pembagian Harta Gono-Gini Saat Terjadi Perceraian: Pentingnya Perjanjian Perkawinan untuk Mengantisipasi Masalah Harta Gono-Gini. Jakarta: PT. Visimedia Pustaka, hlm. 51. 
(2) Jika pengadilan yang memberikan izin untuk beristeri lebih dari seorang menurut Undang-undang ini tidak menentukan lain, maka berlakulah ketentuan-ketentuan ayat (1) Pasal ini.

Dari ketentuan di atas dapat diperoleh sebuah penjelasan bahwa kedudukan istri kedua, ketiga dan keempat dalam perkawinan poligami akibat perceraian tidak mempunyai hak atas harta bersama dari perkawinan suami dengan istri yang pertama, istri ketiga dan keempat tidak mempunyai hak atas harta bersama dari perkawinan suami dengan istri pertama dan kedua, sedangkan istri keempat tidak mempunyai hak atas harta bersama dari perkawinan suami dengan istri pertama, kedua dan ketiga. Dalam Putusan Mahkamah Agung Republik Indonesia Nomor 37 K/AG/1995 tanggal 28 September 1995 telah dinyatakan bahwa jika di antara para pihak telah terjadi kesepakatan untuk menyelesaikan perkara harta bersama secara damai, maka penyelesaiannya harus didasarkan pembagian yang sama rata atas kesepakatan tersebut dan secara damai mengikat pihak-pihak yang mengadakannya.

Secara umum pembagian harta gono-gini baru bisa dilakukan setelah adanya gugatan cerai atau perkawinan bubar karena kematian. Artinya, daftar harta gono-gini dan bukti-buktinya dapat diproses jika harta tersebut diperoleh selama perkawinan dan dapat disebutkan dalam alasan pengajuan gugatan cerai (posita), yang kemudian disebutkan dalam permintaan pembagian harta dalam berkas tuntutan (petitum). Namun, gugatan cerai belum menyebutkan tentang pembagian harta gono-gini. Untuk itu, pihak suami/isteri perlu mengajukan gugatan baru yang terpisah setelah adanya putusan yang dikeluarkan pengadilan. Ketentuan tentang pembagian harta gono-gini didasarkan pada kondisi yang menyertai hubungan suatu perkawinan sebagaimana diatur pada Pasal 38 UU No. 16 Tahun 2019, dan pembagian harta gono-gini karena adanya perkawinan poligami, dapat diuraikan sebagai berikut:

1. Cerai Mati. Cerai mati biasanya dipahami sebagai bentuk perpisahan hubungan suami istri karena meninggalnya suami/istri. Pembagian harta gono-gini untuk kasus cerai mati dibagi menjadi 50 : 50. Berdasarkan Pasal 96 Inpres No. 1 Tahun 1991 mengatur bahwa:

(1) Apabila terjadi cerai mati, maka separuh harta bersama menjadi hak pasangan yang hidup lebih lama.

(2) Pembagian harta bersama bagi seorang suami atau istri yang istri atau suaminya hilang harus ditangguhkan sampai adanya kepastian matinya yang hakiki atau matinya secara hukum atas dasar putusan Pengadilan Agama.

Dari ketentuan di atas dapat diperoleh sebuah penjelasan bahwa status kematian salah seorang pihak, baik suami maupun istri, harus jelas terlebih dahulu agar penetuan tentang pembagian harta gono-gini jadi jelas. Jika salah satu dari keduanya hilang, harus ada ketentuan tentang kematian dirinya secara hukum melalui pengadilan agama.

2. Cerai Hidup. Jika pasangan suami istri terputus hubungannya karena perceraian di antara mereka, pembagian harta gono-gini diatur 
berdasarkan hukumnya masing-masing sebagaimana diatur pada Pasal 37 UU No. 16 Tahun 2019. Yang dimaksud dengan hukumnya masing-masing adalah mencakup hukum agama, hukum adat, dan sebagainya. Bagi umat Islam ketentuan pembagian harta gono-gini diatur dalam Kompilasi Hukum Islam sedangkan bagi penganut agama lainnya diatur dalam KUHPerdata.

Ketentuan pembagian harta bersama bagi penganut agama selain Islam adalah berdasarkan Pasal 128 KUHPerdata mengatur bahwa:

"Setelah bubarnya persatuan, maka harta benda kesatuan dibagi dua antara suami dan istri, atau antara para ahli waris mereka masing-masing, dengan tidak mempedulikan soal dari pihak yang manakah barang-barang itu diperoleh."

Dari ketentuan di atas dapat diperoleh sebuah penjelasan bahwa jika pasangan suami isteri bercerai, harta bersama mereka dibagi dua (50:50). Ketentuan ini tidak berbeda dengan ketentuan dalam Pasal 97 Inpres No. 1 Tahun 1991. ${ }^{4}$

Pembagian harta gono-gini dalam perkawinan yang kedua kalinya (poligami) tidak semudah dalam perkawinan monogami. Namun demikian, pada dasarnya pembagian harta gono-gini dalam perkawinan poligami adalah sama dengan pembagian harta gono-gini di perkawinan monogami, yaitu masing-masing pasangan mendapatkan bagian seperdua. Hanya saja, pembagian harta gono-gini di perkawinan poligami juga harus memperhatikan bagaimana nasib anak-anak hasil perkawinan ini, Dan terdapat pemisahan antara harta perkawinan pertama, kedua, ketiga dan keempat.

\section{B. Pembagian Harta Benda Perkawinan Berdasarkan Inpres No. 1 Tahun 1991}

Apabila seseorang berbicara tentang poligami, maka orang langsung mengira, bahwa Islam sebagai pelopor pelaksanaan poligami. Padahal poligami dalam pandangan Islam merupakan pintu darurat yang hanya sewaktu-waktu saja dapat dipergunakan. Sebagai contoh, pintu darurat yang ada pada pesawat terbang, hanya dalam keadaan terpaksa saja dapat terbuka dan dimanfaatkan. Dalam situasi biasa aman, malahan dilarang membukanya. ${ }^{5}$ Poligami merupakan syariat Islam yang akan berlaku sepanjang zaman hingga hari akhir. Poligami diperbolehkan dengan syarat sang suami memiliki kemampuan untuk adil diantara para istri, bila seorang suami memiliki lebih dari satu istri, wajib baginya untuk berlaku adil di antara mereka, dengan memberikan nafkah yang sama, memberi pakaian, tempat tinggal, dan waktu bermalam. ${ }^{6}$

${ }^{4}$ Syahrani, R. (1980). Masalah Tertumpuknya Beribu-Ribu Perkara di Mahkamah Agung. Bandung: PT. Alumni, hlm. 100.

${ }^{5}$ Hasan, M. A. (2003). Pedoman Hidup Berumah Tangga dalam Islam. Jakarta: Kencana Prenada Media Group, hlm. 269.

${ }^{6}$ As-Sanan, A. A. (2003). Memahami Keadilan dalam Poligami (A. S. Hasan, Trans. H. Hefni Ed.). Jakarta: PT. Globalmedia Cipta Publishing, hlm. 25. 
Harta benda perkawinan dalam UU No. 16 Tahun 2019 dibedakan menjadi 2 (dua) macam, yaitu: ${ }^{7}$

1. Harta Bersama, Harta bersama adalah harta benda yang diperoleh selama perkawinan, tanpa dipersoalkan asalnya baik yang diperoleh dari istri maupun dari suami, semuanya merupakan harta milik bersama suami istri;

2. Harta Bawaan, Harta bawaan adalah harta yang dibawa masuk oleh masing-masing suami istri kedalam perkawinannya. Harta benda yang diperoleh masing-masing sebagai hadiah atau warisan termasuk harta bawaan.

Berdasarkan Pasal 2 Inpres No. 1 Tahun 1991 mengatur bahwa:

"Perkawinan menurut hukum Islam adalah pernikahan, yaitu akad yang sangat kuatatau mitssaqan ghalidzan untuk mentaati perintah Allah dan melaksanakannya merupakan ibadah."

Adapun Pasal 1 huruf f Inpres No. 1 Tahun 1991 mengatur bahwa:

"Harta kekayaan dalam perkawinan atau Syirkah adalah harta yang diperoleh baik sendiri-sendiri atau bersama suamiisteri selama dalam ikatan perkawinan berlangsung selanjutnya disebut harta bersama, tanpa mempersoalkan terdaftar atas nama siapapun."

Penyelesaian perselisihan pembagian harta bersama melalui Pengadilan Agama ini sebenarnya merupakan alternatif yang terakhir, setelah upaya penyelesaian perselisihan secara damai atau musyawarah tidak dapat tercapai diluar pengadilan. Penyelesaian perselisihan pembagian harta bersama secara damai atau musyawarah diantara para pihak kiranya lebih baik, karena para pihak dapat bermusyawarah untuk melakukan pembagian harta bersama sesuai dengan keadaan masingmasing yang dirasa dapat memenuhi rasa keadilan bagi para pihak, dan juga senantiasa masih tetap menjaga hubungan silaturahmi diantara para pihak dengan baik. Tetapi jika jalan damai atau musyawarah tidak tercapai maka diselesaikan di Pengadilan yang diberikan kewenangan untuk memeriksa, mengadili dan memutus suatu perkara pelaksanaan pembagian harta bersama dalam perkawinan poligami setelah perceraian dengan mediasi atau dengan putusan pengadilan.

Pelaksanaan pembagian harta bersama dalam perkawinan poligami setelah terjadinya perceraian, berdasarkan Pasal 94 Inpres No. 1 Tahun 1991 mengatur bahwa:

(1) Harta bersama dari perkawinan seorang suami yang mempunyai isteri lebih dari seorang, masing-masing terpisah dan berdiri sendiri. hlm. 8 .

${ }^{7}$ Mulia, S. M. (2005). Islam Menggugat Poligami. Jakarta: PT. Gramedia Pustaka Utama, 
(2) Pemilikan harta bersama dari perkawinan seorang suami yang mempunyai isteri lebih dari seorang sebagaimana tersebut ayat (1), dihitung pada saat berlangsungnya akad perkawinan yang kedua, ketiga atau keempat.

Tetapi dengan adanya buku pedoman pelaksanaan tugas dan administrasi Peradilan Agama maka penjelasan mengenai harta bersama perkawinan poligami menjadi acuan para hakim, ${ }^{8}$ dalam memutus perkara tersebut yang penjelasannya sebagai berikut: ${ }^{9}$

1. Perkara harta bersama dalam hal suami beristri lebih dari seorang telah diatur oleh Pasal 94 Inpres No. 1 Tahun 1991 tetapi mengandung ketidak adilan karena dalam keadaan tertentu dapat merugikan istri yang dinikahi lebih dahulu, oleh karenanya Pasal tersebut harus dipahami;

2. Dijelaskan bahwa harta yang diperoleh oleh suami selama dalam ikatan perkawinan dengan istri pertama, merupakan harta bersama milik suami dan istri pertama, sedangkan harta yang diperoleh suami selama dalam ikatan perkawinan dengan istri kedua dan selama itu pula suami masih terikat perkawinan dengan istri pertama dan istri kedua, demikian pula halnya sama dengan perkawinan kedua apabila suami melakukan perkawinan dengan istri ketiga dan keempat;

3. Ketentuan harta bersama tersebut tidak berlaku atas harta yang diperuntukkan terhadap istri kedua, ketiga dan keempat (seperti rumah, perabotan rumah tangga, dan pakaian) sepanjang harta yang diperuntukkan istri kedua, ketiga, dan keempat tidak melebihi $1 / 3$ dari harta bersama.

Pengaturan harta bersama berdasarkan UU No. 1 Tahun 1974 dan Inpres No. 1 Tahun 1991, pada dasarnya telah lebih dahulu diatur dalam Putusan Mahkamah Agung Nomor 248 K/Sip/1958 yang ditetapkan pada tanggal 10 September 1958, menyatakan bahwa terhadap harta bersama dalam perkawinan maka bahagian suami istri masing-masing mendapat $1 / 2$ dari harta bersama yang diperoleh selama perkawinan berlangsung.

Dengan adanya pengaturan harta bersama oleh UU No. 16 Tahun 2019, Inpres No. 1 Tahun 1991 serta PMA No. 248 K/Sip/1958, maka secara tidak langsung hak-hak antara suami istri terjamin dan menyejajarkan kedudukan antara suami istri di mata hukum. ${ }^{10}$

Mahkamah Agung Republik Indonesia dengan Surat Keputusan Ketua Mahkamah Agung Republik Indonesia Nomor KMA/032/SK/ IV/2006 yang ditetapkan pada tanggal 4 April 2006 dimana telah memberlakukan Buku II tentang Pedoman Pelaksanaan Tugas dan

\footnotetext{
${ }^{8}$ Busthami, D. (2017). Kekuasaan Kehakiman dalam Perspektif Negara Hukum di Indonesia. Masalah-Masalah Hukum, Universitas Diponegoro, 46(4), hlm. 340.

${ }^{9}$ Editorial. (2010). Pedoman Pelaksanaan Tugas dan Administrasi Peradilan Agama. Jakarta: Direktorat Jenderal Badan Peradilan Agama, Mahkamah Agung Republik Indonesia, hlm. 138.

${ }^{10}$ Lihat Pasal 85, Pasal 86, Pasal 87 Inpres No. 1 Tahun 1991.
} 
Administrasi Pengadilan, yang isinya antara lain mengenai masalah harta bersama dalam perkawinan poligami.

a. Pada saat mengajukan permohonan izin poligami ke Pengadilan Agama/Mahkamah Syari'ah, suami wajib pula mengajukan permohonan penetapan harta bersama dengan istri sebelumnya bersamaan dengan permohonan izin poligami. Apabila suami tidak mengajukannya, maka istri terdahulu (yang belum dicerai) dapat mengajukan gugatan rekonvensi penetapan harta bersama. Apabila istri terdahulu tidak mengajukan gugatan rekonvensi, maka permohonan izin poligami tersebut harus dinyatakan tidak dapat diterima;

b. Harta bersama yang diperoleh selama perkawinan dengan istri pertama harus dipisahkan dengan harta bersama perolehan dengan istri kedua dan seterusnya;

c. Apabila terjadi perceraian atau karena kematian, maka cara penghitungan harta bersama adalah, untuk istri pertama $1 / 2$ dari harta bersama dengan suami yang diperoleh selama perkawinan, ditambah 1/3 dari harta bersama yang diperoleh suami dengan istri pertama dan kedua, ditambah $1 / 4$ dari harta bersama yang diperoleh suami bersama istri ke tiga, istri kedua dan istri pertama, ditambah 1/5 dari harta bersama yang diperoleh suami bersama istri keempat, ketiga kedua dan istri pertama.

Tujuan Mahkamah Agung mengatur harta bersama dalam poligami, adalah untuk menghindari terjadinya penyelundupan hak istri terdahulu oleh suami. biasa terjadi, ketika si istri telah memberi izin kepada suaminya untuk menikah lagi, pada akhirnya istri terdahulu sering tidak diperhatikan, dan hak-haknya dari harta bersama tereduksi oleh kepentingan istri kedua. Oleh sebab itu, Mahkamah Agung menghendaki ada pemisahan yang tegas antara harta bersama suami dengan istri terdahulu ketika suami akan melakukan poligami. Untuk hal tersebut, ajaran agama Islam sangat menghendaki adanya pembukuan yang rapi dan akuntabel, yang dibuat oleh suami istri yang memiliki harta bersama, sehingga tidak terjadi percampuran harta bersama istri pertama, kedua dan seterusnya.

Jadi, jelaslah bahwa harta bersama masing-masing isteri terpisah dan berdiri sendiri hal ini dapat kita lihat pada PMA No. 248 K/Sip/1958 yang mengatur kaidah hukum bahwa, bila mana seorang lelaki kawin dengan lebih dari seorang perempuan, sedangkan ada pula lebih dari gono-gini, maka gono-gini itu dipisahkan.

\section{Efektivitas Pelaksanaan Pembagian Harta Bersama dalam Perkawinan Poligami jika terjadi Perceraian Berdasarkan Hasil Penelitian}

Ada tiga masalah-masalah hukum yang biasanya muncul dalam perkawinan, yaitu masalah hubungan suami-isteri, masalah hubungan orang tua dengan anak, dan masalah harta benda, disamping dua 
masalah yang pertama, disadari atau tidak, persoalan harta benda kerapkali lebih menimbulkan perselisihan dalam perkawinan, sehingga berpotensi mengancam kerukunan rumah tangga, Terlebih lagi, kehidupan perkawinan bagi suami yang mempunyai istri lebih dari seorang (perkawinan poligami). Tentu banyak konsekuensi hukum yang bisa terjadi jika suami tidak mampu berlaku adil. ${ }^{11}$

Menurut fenomena hukum, bahwa dalam perkawinan poligami, yaitu suatu sistem perkawinan antara satu orang pria dengan lebih dari seorang isteri, dalam Hukum Islam dibatasi paling banyak 4 (empat) orang isteri yang tentunya memiliki beberapa syarat yang tidak mudah, yaitu syarat utamanya harus mampu berlaku adil. Dalam perkawinan poligami ini tidak menutup kemungkinan terjadi penyeludupan hak isteri terdahulu oleh suami. Biasa terjadi ketika si isteri telah memberi izin kepada suaminya untuk menikah lagi, pada akhirnya istri terdahulu sering tidak diperhatikan, sehingga hak-hak dari harta bersama tereduksi oleh kepentingan isteri kedua.

Perkawinan adalah salah satu peristiwa yang sangat penting dalam kehidupan masyarakat Indonesia. ${ }^{12}$ Akibat perkawinan itu tidak hanya menyangkut hubungan hukum antara calon suami isteri dalam serial poligami, tetapi juga sangat berhubungan erat dengan orang tua kedua belah pihak, saudara-saudara, bahkan keluarga-keluarga kedua belah pihak. ${ }^{13}$ Harta bersama adalah harta yang diperoleh baik sendiri-sendiri atau bersama suami-istri selama dalam ikatan perkawinan berlangsung, tanpa mempersoalkan terdaftar atas nama siapapun. ${ }^{14}$

Prosedur permohonan perceraian dan pembagian harta bersama: ${ }^{15}$

a. Pada cerai "talak" suami mengajukan permohonan talak kepada Pengadilan Agama disertai dengan permohonan penetapan pembagian harta bersama di antara mereka;

b. Pada "gugat cerai" istri mengajukan permohonan cerai kepada Pengadilan Agama disertai dengan permohonan penetapan pembagian harta bersama di antara mereka.

Persoalan harta bersama dalam perkawinan serial poligami akan menjadi persoalan yang cukup pelit dan rumit, dan dapat berakibatkan pada kerugian bagi istri terdahulu, apabila tidak dilakukan pembukuan yang rapi dan akuntabel, karena tidak menutup kemungkinan, bisa jadi, ketika si istri telah memberikan izin poligami kepada suaminya untuk menikah lagi, pada akhirnya istri terdahulu sering tidak diperhatikan,

\footnotetext{
${ }^{11}$ Wawancara dengan Bannasari, Hakim Pengadilan Agama Kelas 1A Makassar, pada tanggal 28 Januari 2020

${ }^{12}$ Zainuddin, Z., \& Jaya, N. (2018). Jaminan Kepastian Hukum dalam Perkawinan Melalui Itsbat Nikah (Studi di Pengadilan Agama Makassar Kelas IA). Riau Law Journal, Universitas Riau, 2(2), hlm. 189.

${ }^{13}$ Wawancara dengan Alwi Thaha, Hakim Pengadilan Agama Kelas 1A Makassar, pada tanggal 28 Januari 2020.

${ }^{14}$ Wawancara dengan Bannasari, Hakim Pengadilan Agama Kelas 1A Makassar, pada tanggal 28 Januari 2020.

${ }^{15}$ Wawancara dengan Salahuddin Mannahawu, Direktur Kantor Advokat Belawa (Bela Warga), pada tanggal 15 Januari 2020.
} 
dan hak-haknya dari harta bersama tereduksi oleh kepentingan istri kedua, karena suami memiliki kecenderungan terhadap istri kedua. Hal ini yang Mahkamah Agung menerbitkan Surat Keputusan Nomor: KMA/032/SK/IV/2006. mengenai syarat mutlak izin poligami yaitu harta bersama wajib hakim memberikan penetapan harta bersama sebagai syarat mutlak dalam permohonan izin poligami. ${ }^{16}$

Perkawinan poligami syarat yang harus dipenuhi suami untuk bisa dikabulkan permohonan izin poligaminya yaitu: ${ }^{17}$

1. Terpenuhinya Syarat-syarat untuk izin poligami berdasarkan UU No. 16 Tahun 2019;

2. Terpenuhinya syarat-syarat untuk izin poligami berdasarkan Inpres No. 1 Tahun 1991;

3. Terpenuhinya syarat poligami menurut Hukum Islam (Al-Qur'an);

4. Dan harta bersama yang diperoleh selama ikatan perkawinan berlangsung dengan istri pertama, jika ingin berpoligami dengan calon isteri kedua wajib di catat di Pengadilan Agama, harta bersama yang diperoleh selama perkawinan isteri pertamanya, untuk hakim memberikan penetapan harta bersama dalam perkara permohonan izin poligami sebagai syarat mutlak atau syarat wajib untuk dikabulkannya.

Harta benda perkawinan dalam UU No. 16 Tahun 2019 dibedakan menjadi 2 (dua) macam, yaitu: ${ }^{18}$

1. Harta Bersama adalah harta benda yang diperoleh selama perkawinan, tanpa dipersoalkan asalnya baik yang diperoleh dari istri maupun dari suami, semuanya merupakan harta milik bersama suami istri;

2. Harta Bawaan adalah harta yang di bawah masuk oleh masingmasing suami istri ke dalam perkawinannya. Harta benda yang diperoleh masing-masing sebagai hadiah atau warisan termasuk harta bawaan.

Harta benda dalam perkawinan ada empat yaitu: ${ }^{19}$

1. Harta asal atau harta bawaan adalah Harta asal atau harta bawaan yaitu harta yang diperoleh masing-masing pihak yang berasal dari orang tuanya atau keluarga terdekat sebagai hadiah, hibah atau warisan, atau bisa juga dalam bentuk sodaqah dan wasiat. Harta ini menjadi milik masing-masing yang membawanya ke dalam ikatan perkawinan.

2. Harta pencaharian masing-masing sebelum kawin adalah Harta pencaharian masing-masing sebelum kawin yaitu harta yang

\footnotetext{
${ }^{16}$ Wawancara dengan Bannasari, Hakim Pengadilan Agama Kelas 1A Makassar, pada tanggal 28 Januari 2020.

${ }^{17}$ Wawancara dengan Muhtar, Hakim Pengadilan Agama Kelas 1A Makassar, pada tanggal 29 Januari 2020.

${ }^{18}$ Wawancara dengan Bannasari, Hakim Pengadilan Agama Kelas 1A Makassar, pada tanggal 28 Januari 2020.

${ }^{19}$ Wawancara dengan Salahuddin Mannahawu, Direktur Kantor Advokat Belawa (Bela Warga), pada tanggal 15 Januari 2020.
} 
didapat masing-masing pihak sebagai jerih payah dari pekerjaannya sebelum mereka menikah. Harta ini menjadi milik masing-masing sebagai harta bawaan karena merupakan jerih payah yang diperoleh masing-masing sebelum mereka menikah atau kawin.

3. Harta hadiah perkawinan adalah Harta hadiah perkawinan yaitu harta kekayaan yang berasal dari hadiah-hadiah, kado perkawinan atau uang yang di dapat pada waktu resepsi perkawinan berlangsung. Harta ini umumnya menjadi milik bersama suami dan istri.

4. Harta gono-gini atau harta bersama adalah Harta gono-gini atau harta bersama, yaitu harta yang terbentuk selama perkawinan berlangsung yang menjadi milik bersama suami isteri.

Pelaksanaan pembagian harta bersama dalam perkawinan poligami jika terjadi perceraian merujuk pada Pasal 94 Inpres No. 1 Tahun 1991. Jadi jelas pelaksanaan pembagian harta bersama dalam perkawinan poligami yaitu harta bersama dari perkawinan poligami masing-masing terpisah dan berdiri sendiri, pemilikan harta bersama dari perkawinan poligami dihitung pada saat berlangsungnya akad perkawinan yang kedua, ketiga atau keempat. ${ }^{20}$

Pelaksanaan pembagian harta bersama dalam perkawinan poligami jika terjadi perceraian selain merujuk pada Pasal 94 Inpres No. 1 Tahun 1991, juga diatur dalam Pasal 65 UU No. 16 Tahun 2019. ${ }^{21}$ Adapun pembagian harta bersama dalam perkawinan poligami menurut M. Yahya Harahap menyatakan bahwa istri pertama dari suami yang berpoligami mempunyai hak atas harta bersama yang dimilikinya bersama dengan suaminya, istri kedua dan seterusnya hanya berhak atas harta bersamanya bersama suaminya sejak perkawinan mereka berlangsung, kesemua istri memiliki hak yang sama atas harta bersama tersebut, namun, istri yang kedua dan seterusnya tidak berhak terhadap harta bersama milik istri yang pertama. Jadi apa yang menjadi harta bersama antara suami dengan istri yang pertama dalam kehidupan rumah tangga mereka merupakan harta bersama yang terpisah dan berdiri sendiri dari harta bersama antara suami dan istri kedua, istri kedua dan seterusnya, tidak berhak atas harta bersama suami dengan istri pertamanya. ${ }^{22}$

Untuk menentukan yang termasuk kategori harta bersama harus memperhatikan sumber perolehannya harta tersebut dengan melihat fakta hukum tahun mulai terjadinya ikatan perkawinan, hal ini sangat penting untuk memisahkan harta bersama dalam serial poligami, misalnya: ${ }^{23}$

\footnotetext{
${ }^{20}$ Wawancara dengan Alwi Thaha, Hakim Pengadilan Agama Kelas 1A Makassar, pada tanggal 28 Januari 2020.

${ }^{21}$ Wawancara dengan Alwi Thaha, Hakim Pengadilan Agama Kelas 1A Makassar, pada tanggal 28 Januari 2020.

${ }^{22}$ Wawancara dengan Muhtar, Hakim Pengadilan Agama Kelas 1A Makassar, pada tanggal 29 Januari 2020.

${ }^{23}$ Wawancara dengan Alwi Thaha, Hakim Pengadilan Agama Kelas 1A Makassar, pada tanggal 28 Januari 2020.
} 


\section{Gambar 1. Perhitungan Tahun Perkawinan dalam Serial Poligami tanpa Adanya Perceraian}

1980

1984

1994

2017

2020

A

B

C

D

E

Berdasarkan pada gambar 1 di atas ditarik sebuah kesimpulan:24

1. Istri pertama $(A \Rightarrow E)$, menikah dengan suaminya pada tahun 1980, maka harta bersama istri pertama dengan suami terhitung pada tahun 1980 sampai dengan 2020 yaitu 40 tahun pernikahannya;

2. Istri kedua ( $B \Rightarrow E$ ), menikah dengan suaminya pada tahun1984, maka harta istri kedua dengan suaminya terhitung pada tahun sampai dengan 2020 yaitu 36 tahun pernikahannya;

3. Istri ketiga ( $C \Rightarrow E$ ), menikah dengan suaminya pada tahun 1994, maka harta istri kedua dengan suaminya terhitung pada tahun sampai dengan 2020 yaitu 26 tahun pernikahannya;

4. Istri $(C \Rightarrow E$ ), menikah dengan suaminya pada tahun 2017 maka harta istri kedua dengan suaminya terhitung pada tahun sampai dengan 2020 yaitu 3 tahun pernikahannya.

\section{Gambar 2. Pelaksanaan Pembagian Harta Bersama dalam Serial Poligami karena Kematian dan atau Perceraian}
A $\frac{1 / 2}{1 \text { istri }}$
B $\frac{1 / 3}{2 \text { istri }}$
C $\frac{1 / 4}{3 \text { istri }}$
D $\frac{1 / 5}{4 \text { istri }}$
$\mathbf{E}$

Untuk menentukan harta bersama, harus memperhatikan sumber perolehannya harta tersebut dan melihat asal sumber perolehan harta tersebut, yaitu melihat fakta hukum tahun mulai terjadinya ikatan perkawinan dan asal sumber harta tersebut apakah bersumber dari harta bawaan atau harta bersama, hal ini sangat penting untuk memisahkan harta bersama dalam serial poligami, misalnya pada gambar (2) di atas ditarik sebuah kesimpulan bahwa Apabila terjadi perceraian atau karena kematian, maka cara penghitungan harta bersama dalam serial poligami adalah yaitu: ${ }^{25}$

1. Istri pertama: $1 / 2$ dari harta bersama yang diperoleh dan akan terjadi pemisahan dan pengurangan persentase harta bersama saat suami melangsungkan akad perkawinan yang kedua, ketiga dan keempat.

2. Istri kedua: $1 / 3$ dari harta bersama yang diperoleh suami dengan istri pertama dan kedua. Akan terjadi pemisahan dan pengurangan persentase harta bersama saat suami melangsungkan akad perkawinan yang ketiga dan keempat.

\footnotetext{
${ }^{24}$ Wawancara dengan Alwi Thaha, Hakim Pengadilan Agama Kelas 1A Makassar, pada tanggal 28 Januari 2020.

${ }^{25}$ Wawancara dengan Alwi Thaha, Hakim Pengadilan Agama Kelas 1A Makassar, pada tanggal 28 Januari 2020.
} 
3. Istri ketiga: 1/4 dari harta bersama yang diperoleh suami dengan istri pertama, kedua, dan ketiga. Akan terjadi pemisahan dan pengurangan persentase harta bersama saat suami melangsungkan akad perkawinan dan keempat.

4. Istri keempat: $1 / 5$ dari harta bersama yang diperoleh suami dengan istri pertama, kedua, ketiga dan keempat.

Kedudukan harta bersama dalam perkawinan poligami wujud harta bersama terpisah antara suami dengan masing-masing istri dan perhitungan harta bersama dihitung pada saat berlangsungnya akad perkawinan yang kedua, ketiga dan keempat, tujuannya pemisahannya untuk memberikan kepastian hukum terhadap istri pertama yang dipoligami, dan memberikan perlindungan hukum terhadap hak-hak istri pertama terhadap harta bersamanya. ${ }^{26}$ Bahwa untuk menentukan kategori harta bersama dalam perkawinan serial poligami yang harus diperhatikan yaitu: ${ }^{27}$

1. Waktu perolehannya harta tersebut yaitu, harta yang diperoleh baik sendiri-sendiri atau bersama suami-istri selama dalam ikatan perkawinan berlangsung tanpa mempersoalkan terdaftar atas nama siapapun maka dikategorikan sebagai harta bersama, yaitu melihat waktu perolehannya harta tersebut berdasarkan tahun pernikahan dalam serial poligami, dengan bukti buku nikah atau bukti lain yang menurut hukum bisa membuktikan waktu perolehan harta tersebut;

2. Asal sumber perolehan atau tempat perolehan harta tersebut yaitu, karena jika asal sumber perolehan harta tersebut berasal dari harta bawaan maka dikategorikan sebagai harta bawaan walaupun diperoleh dalam ikatan perkawinan berlangsung tetapi sumber perolehannya berasal dari harta bawaan maka dikategorikan sebagai harta bawaan misalnya, warisan, hibah, hadiah, sodaqah dan wasiat yang diperoleh dalam ikatan perkawinan berlangsung oleh salah satu suami/istri maka dikategorikan sebagai harta bawaan;

3. Pembuktian dalam proses persidangan, selain melihat waktu perolehan harta tersebut dan asal sumber perolehan harta tersebut untuk menentukan kategori harta bawaan atau bersama dalam perkawinan poligami yang penting juga dalam proses pembuktian dalam persidangan, karena dalam pembuktian akan membuktikan kebenaran fakta hukum dan kebenaran peristiwa hukum sesuai dengan alat bukti yang diajukan dalam berperkara misalnya alat bukti dalam hukum acara perdata Pasal 164 HIR dan 284 Rbg serta Pasal 1886 KUHPerdata ada lima alat bukti dalam perkara perdata di Indonesia yaitu Surat; Saksi; Persangkaan; Pengakuan; dan Sumpah.

Jadi, yang perlu dipahami untuk menentukan kategori harta bawaan maupun harta bersama, yaitu selain dilihat dari segi pembuktian dalam hukum acara, sumber perolehan harta, asal sumber perolehan harta

${ }^{26}$ Wawancara dengan Muhtar, Hakim Pengadilan Agama Kelas 1A Makassar, pada tanggal 29 Januari 2020.

${ }^{27}$ Wawancara dengan Muhtar, Hakim Pengadilan Agama Kelas 1A Makassar, pada tanggal 29 
Pleno Jure, Vol. 9 (1), Muhammad Kamran Imran, Pelaksanaan Pembagian Harta ... Januari 2020. 
maupun tempat perolehan harta tersebut ini adalah empat pokok unsur utama membedakan kategori harta bawaan maupun harta bersama. ${ }^{28}$

Setidaknya ada lima faktor yang mempengaruhi efektivitas penegakan hukum sebagai berikut: (1) Faktor hukum sendiri; (2) Faktor penegakan hukum; (3) Faktor sarana atau fasilitas yang mendukung penegakan hukum; (4) Faktor masyarakat, (5) Faktor kebudayaan, Efektivitas penegakan hukum sangatlah bergantung pada kelima faktor tersebut karena sangat berkaitan erat dan saling mempengaruhi. ${ }^{29}$

Kelima faktor di atas saling berkaitan dengan eratnya, karena menjadi hal pokok dalam penegakan hukum, serta sebagai tolok ukur dari efektifitas penegakan hukum. Dari lima faktor penegakan hukum tersebut faktor penegakan hukumnya sendiri merupakan titik sentralnya. Hal ini disebabkan oleh baik undang-undangnya disusun oleh penegak hukum, penerapannya pun dilaksanakan oleh penegak hukum dan penegakan hukumnya sendiri juga merupakan panutan oleh masyarakat luas.

Faktor-faktor yang bisa mempengaruhi efektifitas pelaksanaan pembagian harta bersama dalam perkawinan poligami setelah perceraian yaitu, faktor hukumnya sendiri (terutama hukum acaranya), faktor penegak hukum (Hakim yang berintegritas), faktor sarana atau fasilitas yang mendukung penegakan hukum (sarana dan fasilitas dalam hukum acaranya dalam persidangan), faktor masyarakat (kesadaran hukum masyarakat dan kepatuhan atau ketaatan hukum), faktor kebudayaan (adat istiadat yang kuat). ${ }^{30}$

Pendapat di atas dikuatkan pula oleh beberapa hakim di Pengadilan Agama Kelas 1A Makassar, Faktor-faktor yang bisa saja mempengaruhi efektivitas pelaksanaan pembagian harta bersama dalam perkawinan poligami setelah perceraian, yaitu faktor hukumnya sendiri, faktor penegak hukumnya, faktor sarana dan fasilitas yang mendukung penegakan hukum, faktor masyarakat, dan faktor kebudayaan. ${ }^{31}$

Menyelesaikan perkara harta bersama pada serial poligami para Hakim Agama ini merujuk pada nash-nash Al-Qur'an, Undang-undang Nomor 16 Tahun 2019 Perubahan atas Undang-undang Nomor 1 Tahun 1974 Tentang Perkawinan, Yurisprudensi Mahkamah Agung, dan Kompilasi Hukum Islam dan BUKU II (Pedoman Pelaksanaan Tugas dan Administrasi Peradilan Agama sebagai terapan dan hukum positif di Pengadilan Agama). ${ }^{32}$

${ }^{28}$ Wawancara dengan Muhtar, Hakim Pengadilan Agama Kelas 1A Makassar, pada tanggal 29 Januari 2020.

${ }^{29}$ Soekanto, S. (2008). Faktor-Faktor yang Mempengaruhi Penegakan Hukum. Jakarta: PT. Raja Grafindo Persada, hlm. 46

${ }^{30}$ Wawancara dengan Salahuddin Mannahawu, Direktur Kantor Advokat Belawa (Bela Warga), pada tanggal 15 Januari 2020.

${ }^{31}$ Wawancara dengan Alwi Thaha, Bannasari, Muhtar, dan Syahidal, Hakim Pengadilan Agama Kelas 1A Makassar, pada bulan Januari 2020.

${ }^{32}$ Wawancara dengan Bannasari, Hakim Pengadilan Agama Kelas 1A Makassar, pada tanggal 
Tabel 1. Pengetahuan Responden tentang apakah Pelaksanaan Pembagian Harta Bersama dalam Perkawinan Poligami Setelah Perceraian sudah Efektif

\begin{tabular}{c|c|c|c}
\hline \hline No & Kategori Jawaban & Frekuensi & Persentasi \\
\hline 1 & Efektif & 26 & $32,5 \%$ \\
\hline 2 & Kurang Efektif & 54 & $67,5 \%$ \\
\hline 3 & Tidak Efektif & 0 & $0 \%$ \\
\hline \multicolumn{2}{r|}{ Jumlah } & 80 & $100 \%$ \\
\hline
\end{tabular}

Sumber: Data Primer Setelah Diolah, Tahun 2019/2020

Berdasarkan data pada tabel di atas menunjukkan bahwa pengetahuan responden tentang apakah pelaksanaan pembagian harta bersama dalam perkawinan poligami setelah perceraian sudah efektif, di mana diperoleh pengetahuan responden yang menyatakan efektif sebanyak 26 orang atau 32,5\%, pengetahuan responden yang menyatakan kurang efektif sebanyak 54 orang atau $67,5 \%$ kemudian pengetahuan yang menyatakan tidak efektif sebanyak 0 orang atau $0 \%$, hal ini berarti jumlah sampel responden terbanyak yaitu 54 orang atau $67,5 \%$ menyatakan pelaksanaan pembagian harta bersama dalam perkawinan poligami setelah perceraian kurang efektif. Berdasarkan hasil penelitian hukum dan perhitungan hasil kuesioner di atas menunjukkan fakta hukum, bahwa, memang pelaksanaan pembagian harta bersama dalam perkawinan poligami setelah perceraian dari segi empiris di lapangan kurang efektif.

\section{SIMPULAN DAN SARAN}

Berdasarkan uraian di atas, maka efektivitas pelaksanaan pembagian harta bersama dalam perkawinan poligami setelah perceraian dapat disimpulkan sebagai berikut: Efektivitas pelaksanaan pembagian harta bersama dalam perkawinan poligami jika telah terjadi perceraian adalah kurang efektif, oleh karena dipengaruhi oleh beberapa faktor dan tidak tercapainya sasaran atau tujuan yang ditentukan sebelumnya, sehingga derajat ukuran efektivitas belum terpenuhi. Maka rekomendasi diajukan oleh peneliti: Pelaksanaan pembagian harta bersama dalam perkawinan poligami setelah perceraian, perlu adanya aturan hukum positif yang mengatur mengenai pelaksanaan pembagian harta bersama dalam perkawinan poligami, karena dalam hukum positif cuma mengatur mengenai pemisahan harta bersama isteri kedua dan seterusnya, sedangkan pembagian secara lengkap diatur dalam Surat Keputusan Ketua Mahkamah Agung Republik Indonesia Nomor: KMA/032/SK/IV/2006. Dan syarat wajib penetapan harta bersama dalam permohonan izin poligami, perlu juga adanya aturan hukum positif yang mengatur hal tersebut, sehingga dengan adanya aturan hukum positif mengatur kedua hal tersebut di atas, maka masyarakat akan lebih mudah mengakses aturan tersebut, sehingga pelaksanaan pembagian harta bersama dalam perkawinan poligami mempunyai kepastian hukum dalam hukum positif. 
Pleno Jure, Vol. 9 (1), Muhammad Kamran Imran, Pelaksanaan Pembagian Harta ...

\section{DAFTAR RUJUKAN}

As-Sanan, A. A. (2003). Memahami Keadilan dalam Poligami (A. S. Hasan, Trans. H. Hefni Ed.). Jakarta: PT. Globalmedia Cipta Publishing.

Busthami, D. (2017). Kekuasaan Kehakiman dalam Perspektif Negara Hukum di Indonesia. Masalah-Masalah Hukum, Universitas Diponegoro, 46(4), hlm. 336 - 342. doi: https://doi.org/10.14710/ mmh.46.4.2017.336-342

Editorial. (2010). Pedoman Pelaksanaan Tugas dan Administrasi Peradilan Agama. Jakarta: Direktorat Jenderal Badan Peradilan Agama, Mahkamah Agung Republik Indonesia.

Hasan, M. A. (2003). Pedoman Hidup Berumah Tangga dalam Islam. Jakarta: Kencana Prenada Media Group.

Ilyas, M., et al. (2018). Supervision of Fair Execution for Civil Case Decision. Journal of Law, Policy and Globalization, 70, hlm. 101 - 107.

Instruksi Presiden Republik Indonesia. Nomor 1 Tahun 1991 tentang Penyebarluasan Kompilasi Hukum Islam.

Mulia, S. M. (2005). Islam Menggugat Poligami. Jakarta: PT. Gramedia Pustaka Utama.

Penyusun. (2010). Al-Qur'an dan Terjemahan. Bandung: Departemen Agama RI bekerjasama dengan CV. Diponegoro.

Peraturan Pemerintah Republik Indonesia Nomor 9 Tahun 1975 tentang Pelaksanaan Undang-Undang Nomor 1 Tahun 1974 tentang Perkawinan. Lembaran Negara Republik Indonesia Tahun 1975 Nomor 12. Tambahan Lembaran Negara Republik Indonesia Nomor 3050.

Soekanto, S. (2008). Faktor-Faktor yang Mempengaruhi Penegakan Hukum. Jakarta: PT. Raja Grafindo Persada.

Soemiyati. (2007). Hukum Perkawinan Islam dan Undang-Undang Perkawinan (Undang-Undang No. 1 Tahun 1974 Tentang Perkawinan). Yogyakarta Liberty.

Staatsblad Nomor 23 Tahun 1847 tentang Burgerlijk Wetboek voor Indonesie (BW)/Kitab Undang-Undang Hukum Perdata.

Susanto, H. (2008). Pembagian Harta Gono-Gini Saat Terjadi Perceraian: Pentingnya Perjanjian Perkawinan untuk Mengantisipasi Masalah Harta Gono-Gini. Jakarta: PT. Visimedia Pustaka.

Syahrani, R. (1980). Masalah Tertumpuknya Beribu-Ribu Perkara di Mahkamah Agung. Bandung: PT. Alumni.

Undang-Undang Republik Indonesia Nomor 1 Tahun 1974 tentang Perkawinan. Lembaran Negara Republik Indonesia Tahun 1974 Nomor 1. Tambahan Lembaran Negara Republik Indonesia Nomor 3019.

Undang-Undang Republik Indonesia Nomor 16 Tahun 2019 tentang Perubahan Atas Undang-Undang Nomor 1 Tahun 1974 tentang Perkawinan. Lembaran Negara Republik Indonesia Tahun 2019 Nomor 186. Tambahan Lembaran Negara Republik Indonesia Nomor 6401. 
Pleno Jure, Vol. 9 (1), Muhammad Kamran Imran, Pelaksanaan Pembagian Harta ...

Yunus, A. (2020). Hukum Perkawinan dan Itsbat Nikah: Antara Perlindungan dan Kepastian Hukum. Makassar: Humanities Genius.

Zainuddin, Z., \& Jaya, N. (2018). Jaminan Kepastian Hukum dalam Perkawinan Melalui Itsbat Nikah (Studi di Pengadilan Agama Makassar Kelas IA). Riau Law Journal, Universitas Riau, 2(2), hlm. $187-206$. 